\title{
The Conservation Balancing Act: Leader's Guide ${ }^{1}$
}

\author{
Virginia Peart ${ }^{2}$
}

\section{Situation}

The consciousness of Florida residents is aroused. We care about the environment and are committed to conservation. But can we save water and energy without losing the many benefits an abundance of water and energy to heat that water have provided? It's The Conservation Balancing Act: How to conserve water and energy without losing the benefits!

Although Florida is considered to be a waterrich state with more rainfall than most other areas of the country, good quality water is limited in many areas. Why is water quantity a problem? The population has escalated from 500,000 in 1900 to 3 million in 1950 to more than 16 million in 2000. Population growth is not subsiding. Our growing population demands an enormous quantity of water that cannot be ignored.

The impact on the use of energy in Florida parallels the impact of water use. Countless dollars are spent by families on energy to heat water. Next to air conditioning energy costs, the greatest use of residential energy is to heat water. Florida can never be energy independent. Natural gas and fuel to produce electricity must be purchased from other states. Water and energy use should not be ignored by people who wish to conserve resources and protect the environment.

During previous periods of water shortages in Florida, publications with simple techniques have been developed and adapted for use in Florida. Unfortunately, many of the strategies suggested for water conservation have serious flaws: inexpensive flow restrictors that clog; bricks in toilet tanks that disintegrate; washing full loads of clothes can lead to a number of problems demanding more water and energy to correct; holding soiled dishes in a dishwasher for a full load can attract pests.

Previous problems created by these poorly thoughtout strategies have often discouraged the water conservation ethic we would like to instill.

\section{Purpose}

This program will provide the participant with an understanding of how to conserve water and energy without sacrificing benefits in three major water using areas of the home: the bathroom, the laundry, and the kitchen.

1. This document is FCS 3231, one of a series of the Department of Family, Youth and Community Sciences, Florida Cooperative Extension Service, Institute of Food and Agricultural Sciences, University of Florida. Publication date: February 2003. First published: September 1994. Revised: February 2003. Please visit the EDIS Web site at http://edis.ifas.ufl.edu

2. Written by Virginia Peart, former Associate Professor, Housing, Department of Family, Youth and Community Sciences, Cooperative Extension Service, Institute of Food and Agricultural Sciences, University of Florida, Gainesville, 32611. Revised by Nayda I. Torres, Professor, Family and Consumer Economics, Department of Family, Youth and Community Sciences, Cooperative Extension Service, Institute of Food and Agricultural Sciences, University of Florida and reviewed by Dale Dorman, Extension Housing and Environment Specialist-Emeritus, Cooperative Extension Service, University of Georgia.

The Institute of Food and Agricultural Sciences is an equal opportunity/affirmative action employer authorized to provide research, educational information and other services only to individuals and institutions that function without regard to race, color, sex, age, handicap, or national origin. For information on obtaining other extension publications, contact your county Cooperative Extension Service office. Florida Cooperative Extension Service / Institute of Food and Agricultural Sciences / University of Florida / Christine Taylor Waddill, Dean 


\section{The Conservation Balancing Act Materials}

- FCS 3231. The Conservation Balancing Act: Leader's Guide

Four fact sheets for participants:

- FCS 3232. The Conservation Balancing Act: Part I. In the Home

- FCS 3233: The Conservation Balancing Act: Part II. In the Bathroom

- FCS 3234. The Conservation Balancing Act: Part III. In the Laundry

- FCS 3235. The Conservation Balancing Act: Part IV. In the Kitchen

The Fact Sheets can be used alone, but for conservation to have a major impact, the program can be presented in 2 sessions:

First Session: Part I. In the Home and Part II. In the Bathroom.

Second Session: Part III. In the Laundry and Part IV. In the Kitchen.

\section{Procedures}

\section{Selecting an Audience}

The materials for this lesson are appropriate for both adult and youth audiences who might include:

- Family and Community Educators.

- Home Buyers and Home Owner groups.

- Participants in home maintenance and repair and other housing-related classes.

- Home economics classes in public schools, colleges, or technical schools.
- Older 4-H members in Environment, Energy or similar project areas.

- The local utility companies.

- Home editors of daily and weekly newspapers.

\section{Recruiting Methods}

- Introduce the program at other meetings with a sign-up sheet.

- Promote through local media: radio and TV may accept public service announcements. Newspapers have writers and editors who need stories. Talk to a home editor about The Conservation Balancing Act.

- Contact teachers in schools and colleges.

- Talk with appliance store sales managers and ask them to give flyers to prospective washer/dryer or dishwasher buyers, to customers for hot water heaters, or plumbing fixtures.

- A full-service hardware or plumbing store is a good bet.

\section{Preparing for the Lesson}

In each of the parts of The Conservation Balancing Act: Leader's Guide, there is background information or a scenario to be related in a program. Transparencies can be used to emphasize important points. The leader should be familiar with the scenario and the content of each fact sheet. The Leader's Guide provides discussion suggestions.

\section{Presenting the Lesson}

After a few introductory remarks, the leader can relate the scenario or information provided in the 
appropriate part of the Leader's Guide. At the end of each scenario, the appropriate fact sheet can be distributed to the audience.

Each fact sheet has three sections:

SITUATION is an abbreviated form of the Leader's Guide information. This section does not have to be covered during the lesson, but will be useful to people who have attended the lesson or when fact sheets are distributed without a program.

WATER AND ENERGY FACTS includes a table that provides comparisons of costs for "normal" and conserving uses of water and energy for heating water in Florida homes. Each table was generated based on assumptions presented in the APPENDIX.
YOUR CONSERVATION BALANCING

ACT includes a list of suggestions that can help people both preserve the benefits of water and energy use in the home and save water and energy.

At the end of the last lesson, the Leader may direct participants to review what they have learned in The Conservation Balancing Act. What changes in water and hot water use habits will bring about the greatest savings? How can they get the cooperation of their own families to be participants in Their Family Conservation Act? 


\section{The Conservation Balancing Act: Part 1. Introduction}

Note to Leader. The purpose of the beginning of the program is to emphasize the benefits in our lives of water and the energy to heat water and how they can conserve without sacrificing the benefits. We will call this The

\section{Conservation Balancing Act.}

To begin the first session, you may want to ask some questions of the audience:

Where do you get the water for your home?

Is the water pure?

Are you concerned about running out?

Do you believe you can use less water and energy without sacrificing in your household?

\section{Background Considerations: Water, Energy, Cleanliness in Florida}

We couldn't live long in a world without a supply of pure, safe water. How many times a day does each of us turn on a tap for a drink, to wash our hands, to prepare food, to wash clothes or dishes, to bathe, to water plants. The list might go on and on. Don't tell us the "well is dry." We have to have water.

We don't want to live without energy either: gas and electricity. Heating water for bathing, for cleaning, for laundering clothes is important to the way we want to live. And we can't do without electric light and all of the work done by our appliances.

Here is some news. It takes water to produce electricity for our homes. Steam-driven turbines powered by coal, gas or nuclear fission drive electrical generators. Water is used to remove excess heat that is a by-product of electricity generation. About 1 percent of a home electricity bill covers the cost of the water used. That's a small percentage, but it is a lot of water.

More news. It takes energy to provide the water we need in our homes. About 4 percent of our home water bill pays for energy to pump, treat and deliver it. About 21 percent of our waste water bill may be used for energy to treat it. Additionally, the chemicals used to treat water and waste water are energy intensive.

From an environmental point of view, we need to consider: When we use water, we use energy. When we use energy, we use water. This is an important reason to use both water and energy wisely.

\section{Water in Florida - A Precious Resource}

The Floridan Aquifer, a porous layer of limestone up to several thousand feet thick, is estimated to hold as much fresh water as about 20 percent of the water in the five Great Lakes combined. (Water Resources Altas of Florida. 1984. Florida State University.) The supply of water from the Floridan Aquifer seems unlimited. It is not. The crucial fact is that if we take more fresh water from an aquifer than can be replaced in a timely fashion by rain, the remaining fresh water will be contaminated by salt water moving in from the oceans or up from the depths of the Earth.

The mass of fresh water in the upper part of the Floridan Aquifer is in contact with salt water on the Gulf and Atlantic coasts and is underlain by saltwater at some depth everywhere in the state. The aquifer's fresh water is $1 / 40$ th less dense than salt water, so it floats on the salt water. Each time a foot of fresh water is removed above sea level without timely replacement, the saltwater level rises 40 feet. Once part of the aquifer is contaminated by salt (or any other pollutant), it can take decades to 
flush it out. Some aquifer segments can never be restored.

State Water Distribution. The southern half of Florida gets all of its fresh water from rain that falls on it. So 50 percent of the state's area receives only 44 percent of the state's fresh water supply. And, that same southern half is home for 78 percent of the state's permanent population who use 75 percent of the state's fresh water.

Rainfall Distribution. Rainfall is not distributed uniformly throughout the year, between years, or among regions. In that most populated and rain-dependent part of Florida, 70 to 77 percent of the annual rain falls in the six months from May to October. Because the greatest human demand for water occurs during the dry months (Thanksgiving through late spring) water used must come from water stored during the preceding wet season.

Rainfall Available for Human Use. Since most rainfall goes back into the air as water vapor because of evaporation from surfaces and transpiration, by which plants move water from their roots to their leaves where it is released as vapor, only about 25 percent of the rainfall is potentially available for human use.

Further, the purity of both surface and ground waters is a natural function of the living ecosystems of the soils and the wetlands. Human activities distribute impurities in the air and on the ground, from which they are washed into the soil by rain. This contamination is a threat to our water supply.

\section{Impacts on Water Use}

Population Growth. The population of Florida grew from half a million in 1900 to 16 million in 2000. Imagine - a 3,200 percent population growth in 100 years. Additionally, Florida has more than 29 million tourist visitors and many snowbirds who reside here for part of the year. More people-more water is needed.

The Individual/Family Water Use Impact. Though figures for water use in the early part of the century are not available, the Water Resources Atlas of Florida (1984. Florida State University.), indicates that water for all residential uses including lawn watering was about 50 gallons per person per day in 1950 . This residential use of water had grown to over 158 gallons per person per day by 1985 . In Florida, we more than doubled the per person water use in just 35 years. Since the turn of the century the growth of water use has been much greater. The projected use by 2020 is 162 gallons per person per day.

\section{Water Use for Laundry, Cleaning, and} Personal Hygiene. We can estimate that home water use for cleaning and personal hygiene grew from about 50 gallons per week per person early in this century to over 700 gallons a week in 1990. For the state, home water use for cleaning and hygiene can be estimated to have grown from about 25 million gallons per year in 1900 to 6.5 billion gallons per year. Statewide, the water use for laundry, cleaning and personal hygiene grew 260 percent in 90 years.

\section{Energy Does the Work}

Energy plays an important role in the lives of Florida residents. How many times a day do you turn on a light, start a motor, draw hot water and activate the water heater, relax, work and play in a comfortable temperature-controlled environment? Does your electric meter get much rest? And natural gas quietly does it's job heating water and air in homes.

The use of energy is so basic to the way we live, that we accept as normal the necessity of electric and gas bills - griping only from time to time when these bills are higher than we would 
like. We know we can save money by using less energy in our homes, but our efforts are spotty and often we question the effectiveness of the energy conservation techniques we know.

We rarely take time to think about where our energy comes from. Will we ever run out of energy? Will there be resources to provide energy for future generations?

Where does our energy come from? Natural gas was predicted by some in the early 1970s to run out in twenty years. Fortunately, new discoveries of natural gas fields have assured an abundant supply - at least in the near future. And new fields are being identified on a regular basis, but to find new gas, wells are being drilled deeper and deeper into the Earth's surface.

Electrical energy is produced by generators powered mostly by coal, but also by oil, natural gas and nuclear fission. Coal emissions include sulfur compounds that are one cause of acid rain. Also coal burning increases carbon dioxide that many experts believe is creating a greenhouse effect that can warm the climate on the Earth.

A switch from coal to other fuels at this time is costly. Nuclear power is a possibility. A pound of uranium, a potential source for the production of electrical energy, contains nearly three million times the energy in a pound of coal. At present there are 72 nuclear power plants in the country producing about 10 percent of the country's electrical energy. There are three nuclear power plants in Florida at the present time. But concerns have been expressed about the use of nuclear power.

Florida can never be energy independent. Since there are no coal, oil, natural gas reserves in Florida, the state will always be dependent on out-of-state sources for electricity production.

\section{The Other Side of the Conservation Balancing Act - Cleanliness}

Cleanliness acts to break the pathway of infection and disease to healthy people and animals. But beyond health, cleanliness feels good, smells good, tastes good, looks good.

Although we cannot live without water for our bodies, and water is essential for watering house plants, most of the water used in our homes is used for cleanliness. The cleanliness formula is the key for all cleaning.

\section{The Cleanliness Formula}

Is there a cost for cleanliness? What is required to keep our clothes, our foods and our bodies clean? These are the essential ingredients for cleanliness: water and energy (three kinds of energy) as expressed in The Cleanliness Formula:

\section{Water plus heat energy plus chemical energy plus physical energy equals CLEANLINESS}

water (the universal solvent dissolves and rinses soils away);

heat energy (warm or hot water cleans better than cold water);

chemical energy (soap or detergent, disinfectant, and stain remover all help assure better and quicker soil removal and microorganism protection); and

physical energy (some scrubbing and rubbing helps dislodge dirt so it can be rinsed away) and it takes energy to bring the water to us. 
The Conservation Balancing Act is about our responsibility to use the water and energy in the Cleanliness Formula in optimum amounts to get the desired cleanliness benefits.

Cleanliness is priceless and at the same time cleanliness is costly. Costs associated with clean water, energy and the resources required for cleanliness can eat into our pocketbooks. More important, water, energy and other resources are limited. Uncontrolled use can cost our environment.

Water, energy, environment, and cleanliness are all important to us. Can we conserve without sacrificing the cleanliness and comfort we want in our homes? The answer is YES. The most important place to start is to cut the use of water and other resources where they are wasted where they are used without serving any real purpose. Attack Waste!

Everyone should hate waste. We need to remind ourselves that "a penny saved" is MORE than just a penny earned. It is true - NO TAXES.

\section{Water and Energy Facts for the Home}

Note to Leader. At this point you may want to distribute Fact Sheet FCS 3232, The Conservation Balancing Act: Part I. In the Home. Direct participants to Table 1: "Avoiding Home Water and Energy Waste." Make sure your audience understands the table. You can make up your own discussion. The following items can serve as a guide.

\section{Consider Leaks}

Water leaks are more than annoying, they're costly. A "little" leak of one drop a second wastes 7 gallons per day. That is over 2,500 gallons per year. It only costs about \$2.56. Not enough to worry about? Look again. Waste water treatment for that 2500 gallons costs $\$ 4.85$. The total now goes up to about $\$ 7.41$.

Not convinced? What about a steady stream - like one that can happen in a leaking toilet? Twenty gallons a day adds up to over 7,000 gallons a year for a total of over $\$ 21$. You had better do something about this leak.

If the leaking water is hot water, there is a BIG difference. Heating the water for that little drip adds $\$ 3.75$ if you have a gas water heater or a whopping \$28.38 with an electric water heater. The total hot water leak "bill" (water, waste water, gas or electricity) is then either $\$ 11.16$ (with a gas heater) or $\$ 35.79$ with an electric water heater.

With a good-sized, steady leak of hot water, look out. The total "bill" with a gas water heater can be $\$ 31.89$ or $\$ 102.25$ with an electric water heater.

\section{If you have an electric water heater be very careful of wasting hot water.}

\section{Running Water}

Consider also the number of times you turn on a faucet and run across the room to do something else. Maybe you only do this for half a minute two or three times a day. Maybe everyone in the family does the same thing. In the table you can see what happens to your water bill for just 5 minutes (or three minutes) a day. By working with your family to change their water use habits, you may be able to cut your bills by $\$ 15.88$ to $\$ 26.47$ a year. For hot water your savings might be as high as $\$ 39.87$ with a gas water heater or $\$ 127.82$ with an electric one. 
Table 1. Avoiding Home Water and Energy Waste ${ }^{1}$

\begin{tabular}{|c|c|c|c|c|c|}
\hline \multicolumn{2}{|c|}{ For One Person } & \multicolumn{2}{|c|}{ Family of 4} & \multicolumn{2}{|c|}{ Cost Per Year - \$ } \\
\hline $\begin{array}{l}\text { Times } \\
\text { Per Day }\end{array}$ & $\begin{array}{l}\text { Gallons } \\
\text { Per Year }\end{array}$ & Water & $\begin{array}{l}\text { Waste } \\
\text { Water }\end{array}$ & $\begin{array}{l}\text { Energy w/ } \\
\text { Elec. Water } \\
\text { Heater }\end{array}$ & $\begin{array}{l}\text { Energy w/ } \\
\text { Gas Water } \\
\text { Heater }\end{array}$ \\
\hline
\end{tabular}

Leaks - Cold Water

$1 \mathrm{drop} / \mathrm{sec}$

Steady Stream

Leaks - Hot Water

$1 \mathrm{drop} / \mathrm{sec}$

Steady Stream

Running Water - Cold Water

Faucet on Full for 5 Min

$5 \mathrm{Gal} / \mathrm{Min}$

Faucet on Half for 5 min $3 \mathrm{Gal} / \mathrm{Min}$

\section{Running Water - Hot Water}

Faucet on Full for 5 Min $5 \mathrm{Gal} / \mathrm{Min}$

Faucet on Half for 5 min $3 \mathrm{Gal} / \mathrm{Min}$

$\begin{array}{rrrr}7 & 2,555 & \$ 2.56 & \$ 4.85 \\ 20 & 7,300 & 7.30 & 13.87\end{array}$

7

2,555

2.56

4.85

$\$ 28.38$

$\$ 3.75$

20

7,300

7.30

13.87

81.08

10.72

25

9,125

9.13

17.34

15

5,475

5.48

10.40

${ }^{1}$ For assumptions used in the preparation of this table, see the APPENDIX.

To the Leader: After discussing the table go on to talk about how your audience can conserve water and the energy required to heat water, first by cutting waste.

In Parts II, III and IV you will consider specific ways to conserve in the bathroom, laundry and kitchen; the cost savings involved; and how to conserve without sacrificing the important cleanliness benefits we need to keep. 
The Conservation Balancing Act: Part II. In the Bathroom

Note to Leader. It is probably easier to conserve water in the bathroom than in any other room inside a home. The purpose of this part of The Conservation Balancing Act is to remind people of the importance of personal hygiene and health and the role of water and energy today in assuring good personal hygiene and health. The benefits provided by water and energy are important to people, yet we have come to believe we have unlimited resources. As you begin this session, you may want to ask some questions:

How long is the longest time you have gone without a tub bath or a shower? (They may bring up camping trips in the wilderness, after a flood or hurricane or other disaster.)

Were you concerned about cleanliness? How did you manage? (They may have taken a sponge bath or bathed in a river or lake.)

Were you ever glad just to get back to your home and shower?

Continue with this discussion:

You may be surprised to hear: Most of the water used in the home is used in the bathroom. Let's take a good look at this use of water as we consider how we can balance our water and energy use against the benefits we want to maintain.

The modern bathroom is about aesthetics and personal hygiene. There are millions of people alive today who owe their sight, their health, and their very lives to such trivial things as soap and water and laundry detergent and plumbing.
In the booklet, Cleanliness and the Health Revolution, Dr. V.W. Greene outlines how cleanliness has come to be recognized as a vital component of health ${ }^{1}$ : In the United States today, clean people and clean surroundings are so well accepted that it is hard to imagine an era when this was not the case. Clean air and water are assumed to be inalienable rights. Litter-free streets and public garbage disposal are traditional responsibilities of local governments. Showers, toilets, baths, soap, detergents, laundry equipment, dishwashers, and vacuum cleaners are indispensable features of our lives. They are axiomatically associated with good health, good manners, good rearing, good housekeeping, - in short, our idea of civilization.

It may surprise you to hear that today's accepted standards of environmental and personal hygiene are very recent concepts. The early 1800s in Europe and America were years of filth, poverty, and disease. The sanitary movement didn't begin until the latter part of the 19th century. In 1869 Massachusetts established the first State Board of Health and within nine years, 16 other states followed. Public water systems and sewers were built. Chlorination was introduced about 1915. Toilets began to replace outhouses and chamber pots. A nearby lavatory in bathrooms made it possible to wash hands after using the toilet.

Even more important than legislative enactments and the introduction of public water and supplies was the need for education and hygiene rules. Thus began a program to educate. This was no small task, but public health workers persevered, and gradually during the next 150 years the sanitary consciousness and habits of Western man were fundamentally altered. To our great benefit!

Many types of diseases have been reduced or eliminated by water chlorination, antibiotics, better refrigeration and vaccines. Many other disease types still appear where personal hygiene 
and cleanliness are neglected. Here is a sampling from forty diseases transmitted from person to person whose major control strategy involves personal hygiene: infant diarrhea, viral gastroenteritis, viral hepatitis, ringworm, salmonellosis, typhoid, some staphylococcal and streptococcal infections, typhus, and trachoma. These same diseases are returning in many wartorn areas of the world today - where civilization and sanitation are destroyed.

Personal hygiene practices such as bathing and laundering, though long a part of the lifestyle of certain socioeconomic groups, gradually became popular and established sociobehavior features of America during the quarter century 1890 to 1915 . The revolution was extended during the 20th century. Consider the major causes of death early and late in the century:

\section{FACT:}

The top three leading causes of death in the United States in 1900 were pneumonia and influenza; tuberculosis; and diarrhea. All are infectious. We now have antibiotics to bring about cures for these infectious diseases, but personal hygiene and cleanliness have made an important contribution as well.

In 1960, the top three leading causes of death were diseases of the heart, malignant neoplasms, and vascular lesions affecting the central nervous system. None of these are caused primarily by infection. The most serious infectious diseases are no longer a serious death threat, thanks to the progress made.

\section{FACT:}

As testimony to improved cleanliness and hygiene, the per capita use of toilet soap grew from 1.2 pounds in 1906 to 3.5 pounds in 1977.

Perhaps the most important effect of the health revolution has been a change in attitude toward disease and untimely death. Today, they are not looked upon as inevitable. Instead, today we expect a newborn baby to live, expect a disease to be prevented or cured, expect a life free from pain, debilitation, and sudden premature termination. Personal hygiene and cleanliness play an important part in those perceptions.

The revolution is not over. Vigilance is necessary to protect our important good health heritage. In the early part of this century people struggled to protect their health from infection and disease through proper laundering practices. How well did they do with personal hygiene and cleanliness?

\section{Then}

How did families manage personal hygiene and cleanliness in the GOOD OLD DAYS? Were the processes costly? Were they effective? Did they severely impact the environment? Turn back the clock to the early part of the 20th century.

In Martha Ann Brownly's home there was no running water, heating fuel was expensive, bathing soap was hard to get, there were no toilets. There was an outhouse and chamber pots for use at night. Outhouses were cold in the winter, and always uncomfortable and disagreeable-smelling.

There was a wash basin in the kitchen where hands were washed mainly to remove visible dirt. In the winter bathing was done once a week, usually on Saturday night in the kitchen - the warmest room of the house. Perhaps they used a washtub with water heated by teakettle or in the reservoir in the kitchen stove or maybe they used a washbasin with warm water. In summer, bathing could be done on the back porch.

Bathtubs and toilets were found in some urban homes, some even in new rooms called 
bathrooms. Even there, hot water had to be carried to the bath tub in most homes with water in the early 20th century - because there were no pipes to carry the water into the home. In an unheated bathroom bathing was usually a quick job.

Personal hygiene and cleanliness. Were the processes to achieve them costly early in the 20th century? It is difficult to estimate. Without running water, people used water for washing hands and taking baths sparingly. No water was used with outhouses.

Were personal hygiene and cleanliness methods used effective? Not enough. Infectious diseases were much more common than they are today. The location of drinking water wells and outhouses and farm animal buildings did not always protect the safety of drinking water and contributed to bacterial infections and diseases.

\section{How was the environment affected?}

Certainly the use of water was limited. Soap for washing was biodegradable. Few chemicals were used. Probably the most environmental detriment might be from an outhouse if it were located where it might contaminate water in a drinking water well. Properly located and maintained an outhouse would present no longtime detrimental effect.

\section{Now}

Shannon White-Bixby's family in 2000 has high personal hygiene and cleanliness standards. Look at their bathroom - a marvel in porcelain, chrome, ceramics, glass, plastics and fiberglass with a shower and/or bathtub, maybe a tub with a whirlpool, a lavatory - probably built into a cabinet, maybe two lavatories - his and hers, a toilet, maybe a bidet. Shannon's great grandmother, Martha Ann Brownly, would be amazed to be in such a place. And wonder of wonders, there may be two, two and a half or three bathrooms. No lines waiting to get in.
With a source of water that never runs dry and a water heater to provide all of the hot water wanted, lots of water is used by the family: water for washing hands and face; for brushing teeth; water for bathing; water for shampoos; water for toilet flushing - and that's not all. A lot of towels and washcloths are used. This is a big component for the White-Bixby laundry basket.

What about all of the soap, shampoo, tooth paste, and bubble bath chemicals? Fortunately, these materials are all biodegradable and will be removed in sewage treatment plants where all of the waste water goes after it drains from tubs, sinks and toilets. The largest impact may be that the White-Bixbys use a lot more water, energy, and bathing-related chemicals than were used 90 to 100 years ago. Energy resources are required to produce and provide these conveniences and to treat the waste water that they produce.

Personal hygiene and cleanliness. Are the processes to achieve them costly late in the 20th century? According to Table 2, a family of four might spend $\$ 648$ each year if they have an electric water heater ( $\$ 221$ each year if gas) for water for the toilet, showering, brushing teeth, washing hands and face and laundering bathroom towels. The energy cost for heating the water is shown to be about $77 \%(30 \%)$ of the total cost of water use in the bathroom.

Note however, the water and energy use values in the table are for fairly moderate use of water. Our water and energy bills for personal hygiene and cleanliness are often much higher because we fail to realize the costliness of excess use of water and water that is lost through leaks.

\section{Are personal hygiene and cleanliness} methods used effective? Our standards are high. And our methods are effective, and people must be alert to the dangers of the spread of contagion and disease. There are people who question 
frequent bathing and other cleanliness practices because of their impact on the environment. Anyone pushing civilization back to the "good old days" that never really existed can certainly succeed in recreating the days of filth and illness that did exist.

Washing after using the toilet and before eating are as important as ever. Children should be taught to do this regularly.

\section{How is the environment affected by our} personal hygiene and cleanliness practices? There is no doubt that both water and energy are used. Water and energy make an important contribution to our health. Certainly, our personal hygiene and health are worth protecting from disease, uncontrollable plagues and contagion. It is the waste and misuse that can be identified and reduced that will be of great importance. We need to capture an informed conservation conscience that will master our use of water and energy.

The lessons of personal hygiene and cleanliness were learned slowly over a long period of time and some of the lessons have faded somewhat, even though they may be more important now than ever before. While new chemicals and antibiotics appear regularly to combat disease and infection, viruses and bacteria can become resistant. People develop sensitivities and allergic reactions to antibiotics. Consider, too, people are more mobile than they were just a few decades ago. New Asian Flu viruses can arrive in one day's time. A scary new bacteria is reported to digest the skin and flesh on our bodies.

\section{Water and Energy Facts for the Bathroom}

Our best defense now, and especially now, is to not lose the personal hygiene and cleanliness progress we have already made. The answer to water conservation is not to abandon the use of water and energy. We do need to study how we can use water and energy to the best advantage, efficiently, with little waste.

Note to Leader. At this point you may hand out Fact Sheet FCS 3233. The Conservation Balancing Act: Part II. In the Bathroom. Discuss Table 2 which also appears in the fact sheet. Go through the chart with the participants to familiarize them with the contents.

Notice that the gallons of water of each use is given for each activity. Most activities are performed once a day per person. Over a year's time that can amount to a lot of water; one person might use as much as 15,330 gallons of water just to flush a conventional toilet. Now look at the next two columns: the cost for the water and waste water treatment. The water bill for a family of four would be over $\$ 60$ a year. Then add $\$ 116$ for the waste water bill. This is an expense you can really work on.

Showering can also be a big contributor to water and waste water bills. Warm showers? Look out for the cost of heating the water. It is much higher if you have an electric water heater. But even with gas, heated shower costs go up. Example: Add the annual costs for water, waste water treatment, and water heating for a family of four when they each take 10-minute showers daily:

With an electric water heater:

$$
\$ 73+138.70+\$ 405.38=\$ 617.16
$$

With a gas water heater:

$$
\$ 73+138.70+\$ 53.59=\$ 264.29
$$

These costs don't include running water to get it hot. Let's look for some improvements. 
Table 2. Avoiding Bathroom Water and Energy Waste ${ }^{1}$

\begin{tabular}{|c|c|c|c|c|c|}
\hline \multicolumn{2}{|c|}{ For One Person } & \multicolumn{2}{|c|}{ Family of 4} & \multicolumn{2}{|c|}{ Cost Per Year - \$ } \\
\hline $\begin{array}{l}\text { Times } \\
\text { Per Day }\end{array}$ & $\begin{array}{l}\text { Water } \\
\text { Gallons } \\
\text { Per Year }\end{array}$ & Water & $\begin{array}{l}\text { Waste } \\
\text { Water }\end{array}$ & $\begin{array}{l}\text { Energy w/ } \\
\text { Elec. Water } \\
\text { Heater }\end{array}$ & $\begin{array}{l}\text { Energy w/ } \\
\text { Gas Water } \\
\text { Heater }\end{array}$ \\
\hline
\end{tabular}

Flushing

$\begin{array}{lrrrr}6 \text { gal } & 7 & 15,330 & \$ 61.32 & \$ 116.51 \\ 3 \text { gal } & 7 & 7,665 & 30.66 & 58.25\end{array}$

Showering Warm - Normal Shower (5 Gal/Min)

$\begin{array}{lrrrrrr}10 \text { min } & 1 & 18,250 & 73.00 & 138.70 & \$ 405.38 & \$ 53.59 \\ 3 \min & 1 & 5,475 & 21.90 & 41.61 & 121.61 & 16.08 \\ \text { Navy (3 gal) } & 1 & 1,095 & 4.38 & 8.32 & 24.32 & 3.22\end{array}$

Showering Warm - Low-Flow Shower (3 Gal/Min)

$\begin{array}{lrrrrrr}10 \min & 1 & 10,950 & 43.80 & 83.22 & 243.23 & 32.15 \\ 3 \min & 1 & 3,285 & 13.14 & 24.97 & 72.97 & 9.65\end{array}$

\section{Showering Cold (3 Gal/Min)}

$\begin{array}{lrrrr}10 \min & 1 & 10,950 & 43.80 & 83.22 \\ 3 \min & 1 & 3,285 & 13.14 & 24.97\end{array}$

\section{Bathing Warm}

$\begin{array}{lcccccc}\text { Full Tub (30 gal) } & 1 & 10,950 & 43.80 & 83.22 & 243.23 & 32.15 \\ \text { Half-Full Tub (15 gal) } & 1 & 5,475 & 21.90 & 41.61 & 121.61 & 16.08\end{array}$

Brushing Teeth

$\begin{array}{lllll}5 \text { gal } & 2 & 3,650 & 14.60 & 27.74 \\ 2 \text { gal } & 2 & 1,460 & 5.84 & 11.10\end{array}$

Shaving (One Person)

$\begin{array}{lrrrrrr}5 \text { gal } & 1 & 1,825 & 1.83 & 3.47 & 10.13 & 1.34 \\ 2 \text { gal } & 1 & 730 & 0.73 & 1.39 & 4.05 & 0.54\end{array}$

Washing Hair

$\begin{array}{lrrrrrr}10 \mathrm{gal} & 2 \text { times } / \mathrm{wk} & 1,040 & 4.16 & 7.90 & 23.10 & 3.05 \\ 5 \mathrm{gal} & 2 \text { times } / \mathrm{wk} & 520 & 2.08 & 3.95 & 11.55 & 1.53\end{array}$

${ }^{1}$ For assumptions used in the preparation of this table, see the APPENDIX. 
Flushing the toilet and showering both use tremendous amounts of water. Just putting a one gallon jug of water in the toilet tank can conserve 2,500 gallons of water per person per year. A low flush toilet can save 7,500 gallons per year per person. These changes can bring about substantial water and waste water savings for a family.

The cost of heating water is expensive, especially if a family uses an electric water heater. Call attention to this table in their Fact Sheet comparing the costs of showering by different ways shown in their fact sheet:

Table 3. Annual Costs - Family of 4

$\begin{array}{lrrrr} & \text { Water } & \begin{array}{l}\text { Waste } \\ \text { Water }\end{array} & \begin{array}{l}\text { Energy } \\ \text { Elec. } \\ \text { Water } \\ \text { Heater }\end{array} & \begin{array}{l}\text { Energy } \\ \text { Gas } \\ \text { Water } \\ \text { Heater }\end{array} \\ \text { Normal } & \$ 73.00 & \$ 138.70 & \$ 405.38 & \$ 53.59 \\ \text { Shorter } & 21.90 & 41.61 & 121.61 & 16.08 \\ \text { Navy } & 4.38 & 8.32 & 24.32 & 3.22 \\ \text { Low-Flow } & 43.80 & 83.22 & 243.23 & 32.15 \\ \text { Cold, } & 43.80 & 83.22 & 0.00 & 0.00 \\ \text { Low-Flow } & & & & \end{array}$

Add up the costs of water, waste water and energy for each of the shower types:

Table 4. Total Annual Showering Costs - Family of 4

\begin{tabular}{rr}
\hline $\begin{array}{r}\text { With Electric } \\
\text { Water Heater }\end{array}$ & \multicolumn{2}{l}{$\begin{array}{l}\text { With Gas } \\
\text { Water Heater }\end{array}$} \\
$\$ 617.08$ & $\$ 265.29$ \\
185.12 & 79.59 \\
37.02 & 15.92 \\
370.25 & 159.17 \\
127.02 & 127.02 \\
\end{tabular}

What kind of shower do you take? Is there an alternative that will save? What about other members of your family? What can you do with a little extra money?

Showering, bathing and flushing the toilet offer the most potential for conserving water in the bathroom, but efforts to conserve water and energy should include all uses of water. Wasting water can be the most costly conservation mistake of all. No benefits can justify waste.

Endnote 1.Excerpts from Cleanliness and the Health Revolution. Dr. V. W. Greene. 1984. The Soap and Detergent Association.

Note to Leader: After discussing the table, go on to talk about how people can conserve water, waste water and the energy required to heat water in the bathroom. Discuss the list that follows the table in their fact sheet for specific ways to conserve water and the energy to heat water for personal hygiene and cleanliness in the bathroom. Ask which of the ideas they now use. Which will they try? 


\section{The Conservation Balancing Act: Part III. In the Laundry}

Note to Leader. The purpose for this part of the program on using water and energy more efficiently is to inform people about the laundry process; why such exactness was necessary to get laundry clean clothes when people had to rely on hard work and ingenuity to get good results; why contemporary methods provide satisfactory results with much less labor and precision; and what we now pay, in water and energy use.

This will lead to a discussion of how they can use water and energy more efficiently when laundering clothes. It can help people to balance their laundry practices with their conservation efforts.

As you begin, you may want to involve your audience by asking some questions, such as:

Has anyone in the audience used a wringer washer? (Wringer washers are still available in some locations. Allow some discussion.)

Has anyone used a scrub board to wash clothes? (If some people have washed clothes with a scrub board, ask if they will hold up their hand as you tell the story when you relate an activity that is familiar to them.)

\section{Home Laundry - Strategies Then and Now}

"Man may work from sun to sun, but woman's work is never done."

This was true the early part of the 20th century. Chores were assigned to each day of the week:
Monday - laundry.

Tuesday - ironing.

Wednesday - mending.

Thursday - odd jobs.

Friday - cleaning.

Saturday - baking.

Sunday was church day.

There was little time for recreation as we know it - and little free or unstructured time.

Today, life is easier physically. Our homes offer space for relaxing, entertainment and the wonders of technology that provide equipment to do a lot of the physical work that was once the career - the lifework - of women of the family.

Technology has put near-miracle laundry appliances, laundry aids and fabrics into the family's hands and has made the cost of energy to use the equipment affordable. Today a lot of water and energy are used to provide the good life.

\section{Laundry Then}

Wearing clothes until they were soiled was acceptable in earlier times. Practical considerations involved not having a large wardrobe (for frequent changes) and having to wash and iron those clothes. Considering the standards of 2000, the physical strength and endurance of women and the scarcity of resources, we can see why CONSERVATION was imperative.

Laundering clothes was just one of many labor-intensive chores for homemakers. Washing and ironing could be expected to take two full days of each and every week. Conservation to save the energy involved in laundry also reduced the use of water and other resources.

How was laundry done in the GOOD OLD DAYS? What did it cost in labor, resources and 
dollars? Turn back the clock to an early part of the 20 th century.

Like most people in Florida in the early part of the 20th century, Martha Ann Brownly lives on a farm near a small town. It's Monday morning, July 5, 1921. This is wash day. Martha Ann learned how to wash clothes from her mother. The process is inflexible. Martha Ann knows that each step is necessary to have clean, bright, fresh clothes. She knows it is important to take good care of her clothes and household "linens" like sheets, towels, table cloths, napkins and handkerchiefs. The appearance of her family's clothes and home are marks of success as a homemaker: She and her neighbor women often compare how white their washes look, how early in the morning they get their wash on the clothesline.

Almost everything in the Brownly family wash is cotton - except tablecloths and handkerchiefs which are linen. Household linens are white. All fabrics are natural. (Manmade fibers haven't been invented yet.) Dyes are natural, too, and are usually not color-fast. Clothing types range from delicate embroidered, handmade items to heavy work clothes. While the cleanliness standards of the Brownly household are considered to be quite high, clothes are worn several days - washed no more than weekly. Since play and work are active, clothes have ground-in dirt and stains.

Think for a minute about what has to be done to produce clean, fresh-smelling clothes without today's labor-saving devices, without hot running water, without running water at all. What does Martha Ann teach her daughter, Becky, so she will be a success in the eyes of her neighbors and friends when Becky has a home of her own.

Learn the TEN important laundry principles Martha Ann had to keep in mind on laundry day in 1921.

\section{The Process Then}

Martha Ann, the homemaker, got up early to build a fire in her wood-burning kitchen stove.

She must carry in water from rain barrels for washing clothes two buckets at a time. The big, ten-gallon clothes boiler is first placed on the wood stove and filled with water, the fire that will bring it to a boil in 30 minutes is lighted. Three tubs are set up: one for washing clothes, two for rinsing clothes.

1. Q. Why rain water instead of well water?

A. Rain water is soft. Soft water is needed for washing with pure soap. Well water can be full of minerals that make it hard.

As a practical, thinking homemaker Martha Ann began the laundry process the night before by gathering some of the clothes to be washed. Heavily soiled items were sorted out and put in a tub with soap to soak overnight. Dry beans were also sorted, washed, and put in a kettle to soak until morning.

2. Q. Why soak clothes?

A. Soaking helps loosen heavy, ground-in soil. Saves on the drudgery of scrubbing on a scrub board.

There are other big jobs for Martha Ann to do on wash morning while the water heats:

- Strip the beds, gather nightgowns and pajamas.

- Gather all the towels - dish towels, bath towels.

- Take clothes from laundry hampers. 
Now it is time for Martha Ann to sort the laundry. How many batches or loads of clothes will there be? Many. Martha Ann wants to wash the cleanest clothes first, because the same water will be used again and again until all batches have been washed and rinsed. Whites in the hottest water, maybe two or three batches; colors in cooler water, two or three colored clothes; and two batches of heavy work clothes. And if the water stays clean enough, she can wash some throw rugs at the end.

3. Q. Why sort clothes so carefully? A. Most dyes were not colorfast. Using cooler water protects colors. Also, dirt from heavily soiled, colored clothes can be transferred to cleaner clothes -- that's why they were washed last.

All the wash must be inspected for stains or difficult spots during sorting so Martha Ann can give spots extra scrubbing.

While the water in the clothes boiler is heating, Martha Ann makes starch. Powdered cornstarch is mixed with a little cold water, then boiling water is poured from a tea kettle. Quick stirring keeps lumps from forming. The starch is covered after cooking so film won't form and leave a starchy lump on clothes being starched.

(Martha Ann puts the beans she soaked overnight on to cook slowly. They will be done by suppertime when she won't have much energy left for cooking.)

By now, the washing water is probably hot enough to begin. Martha Ann puts hot water into the wash tub with some cold water for washing the first load of white clothes. Her hands are tough from hard chores: They are accustomed to the very hot water that makes her white clothes whiter.

\section{Q. Why very hot water for white clothes?}

A. Pure soap works best with hot water.

Now she is ready to tackle the first load of white clothes.

A bar of Martha Ann's homemade soap is placed on the little shelf at the top of the washboard. The washboard goes into the side of the tub. Martha Ann handles each item separately. She rubs soap over spots and soiled areas on collars, cuffs. She scrubs these areas until they are clean. She then runs the bar of soap lightly over the rest of the item and lightly scrubs it. Some dirt and soap stay in the water as Martha Ann rinses each item in the wash water. Then, using a vigorous movement of fingers and wrists, she wrings excess water out of each item.

(In some parts of the South, a battering board was used in place of a washboard: Soiled clothes were placed on the battering board and beaten with a stick to loosen soil on clothes.)

5. Q. Why more scrubbing on just heavily soiled areas?

A. They need scrubbing to come clean. Unnecessary scrubbing makes fabrics wear out faster, and you don't really want to do any extra work.

The clothes from this first load go into the boiler on the stove. While the water and clothes boil for about 30 minutes, there is time to clean the clothesline with a damp cloth, set the clothes basket next to the final rinse tub, and get the clothespin apron ready to use. 
6. Q. Why boil the laundry?

A. Boiling disinfects it.

After the first load has been boiled, Martha Ann removes them, item at a time, with a wooden stick and put them in the first rinse tub. She churns the clothes up and down in the rinse water to get out as much leftover soap as possible. Any soap left on turns fabric yellow when ironed.

Everything is wrung out and put in the final rinse water to which bluing has been added. Martha Ann again churns each item well and wrings it out. Shirts, tablecloths, napkins and dresses are starched with the starch she made. Now, the first batch of clothes is ready to be hung.

7. Q. Why bluing?

A. Bluing masks the gray or yellow soap left on fabrics, making white fabrics look whiter.

Becky, Martha Ann's daughter, helps her with the laundry. After the first load is rinsed in the final rinse, she can start hanging clothes on the clothesline. Everything must be hung to dry on the clothesline, item by item. Becky puts the white clothes in the sun for an extra bleaching. Colored clothes are put in the shade. Martha Ann hopes it will not rain on wash day. If it does, she will put a make-shift clothesline on the porch. If clothes are on the line and she hears thunder, she must rush to take the clothes in.

8. Q. Why use starch?

A. New fabrics were usually processed with sizing to give them body and a smooth finish. Sizing washes out, but starch restores the smooth finish when items are ironed.
9. Q. How does the environment help Martha Ann get good laundry results? A. Radiation from the sun bleaches and disinfects (good for white clothing). It also fades colors (protect colored clothes).

Each load of wash goes through the same process: each item is washed individually, scrubbed, rinsed, wrung out and hung to dry. Sheets are hard to wring because of their size. Work clothes, because of their weight and stiffness, are even harder to wring out. But Martha Ann and Becky persist.

Finally, all batches have been washed. The water still looks clean enough to wash a throw rug soiled from people wiping their dirty shoes on it.

10. Q. What does Martha Ann do for the environment? What does she do with the dirty wash and rinse water when the washing is done?

A. In warm months, rinse water is poured in the garden or on the flowers. Wash water is poured somewhere in the yardthe soap she made and used is completely "biodegradable," though Martha Ann never heard of the word.

\section{Laundry Costs Then}

\section{Remember the Cleanliness Formula.}

Cleanliness $=$ water + heat energy + chemical energy + physical energy 
Each of the elements in the Cleanliness Formula carry a cost: a cost in water, a cost in energy as well.

How much water? How much does it cost? Good, soft rainwater was used. Maybe 60 gallons were used for washing, rinsing, boiling and starch-making for the eight or 10 batches of wash. This averages six gallons for each load. About 3000 gallons/year total for the Brownly family. The cost? The water was free. It came from rainfall. The cost involved was Martha Ann's physical labor collecting, then carrying the water into the house and out again.

\section{How much heat energy? What cost?}

Water was heated for washing and for boiling some clothes. The cost? Wood was burned. Wood, a renewable resource, was probably cut from trees on the Brownly's land. The cost involved was the effort of cutting the tree and splitting logs into pieces small enough to put into the wood stove, plus the physical labor to haul firewood into the house.

\section{What chemical energy was used in the cleaning process? What cost? Pure soap and} soft water helped to ensure clean clothes. The soap was made from byproducts of food production (meat slaughtered for food). No depletion of natural resources, no nonbiodegradable materials to introduce into the environment. The cost? A can of lye to make animal fat into soap might have cost 15 cents. The big cost: the physical energy that went into making the soap.

What mechanical energy was used to clean the clothes? What cost? Heavily soiled areas of the wash were scrubbed until clean on a scrub board. Physical labor was needed to apply the soap and to remove soil by scrubbing until the soil was gone. Clothes were churned up, down, and around during the wash and rinse steps. Each item wrung out. Wet clothes carried to the yard and hung on lines to dry. How much energy was used? Hours of it. The cost? Martha Ann and Becky were very tired at the end of wash day, but this great source of energy (physical labor) is renewable. Physical energy always returned in time for ironing the next day.

\section{Environmental Impact}

Except in cities, environmental impacts were probably negligible this early in the 20th century. Almost everything used in the laundry process in rural areas where most people lived was recycled or recyclable.

\section{Laundry Now}

This is the way we wash our clothes TODAY.

It's Friday evening, July 1, 2000. Shannon White-Bixby, Becky's 34-year-old granddaughter (and Martha Ann's great-granddaughter) is washing a load of clothes. Any day of the week can be a washday. A load is usually washed when the laundry hamper is full, the family is running out of clean towels or Shannon's daughter needs a clean pair of jeans. Who does the laundry in the White-Bixby home? Anyone in the family, because everyone is busy, the job isn't considered difficult and may go to whoever needs clean clothes, or whoever has time.

Most clothes the White-Bixby family wears are casual. What about fabrics? Items of clothing and household launderables are made from a variety of fabrics including $100 \%$ cotton, $100 \%$ rayon, $100 \%$ manmade fabric and blends of the above - not to mention washable woolens. Fabrics often have wrinkle-resistant finishes. Colors are usually colorfast, but Madras and other imported fabrics that fade during laundering are popular. Ironing is limited to a few items of clothing. Other items, where the feel of untreated natural fibers is desired, can be acceptable if unironed. Napkins and some other items have been replaced by paper products 
reducing the laundry load. Bed linens are mostly synthetics blended with cotton that need no ironing.

Not only is dress more casual and ironing more a matter of taste than custom, there isn't the pressure on homemakers to have the cleanest, whitest laundry in the neighborhood. Most families, including the White-Bixbys, use a clothes dryer - not the highly visible and weather-dependent outdoor clothesline. Finally, when clothing becomes discolored, the cost of replacement is minor.

Items to be washed include delicate-looking lingerie (that can be quite durable made with synthetics), all cotton or cotton-blend towels, sheets and pillowcases, knitted dresses, sport shirts and jeans. Washer and dryer cycles ranging from delicate, low and high water temperatures and presoak can accommodate the variety of fibers and fabrics in the family wash. Today's detergents are engineered to soften water, remove soil and hold it in suspension, sometimes bleach, brighten and even soften fibers.

\section{Does Shannon use the TEN important} laundry principles Martha Ann had to keep in mind on laundry day in 1921? Hardly.

\section{The Process Now}

Over the years our standards of cleanliness and aesthetics have changed. People no longer accept spots, soil or odors on clothes. Children's clothes are sometimes changed several times a day. Many clothes are washed after only a few hours wearing so they will appear fresh.

Our high standards are easily within reach with little effort and little dollar cost.

CONSERVATION, so important in the past, cannot further reduce the little labor now required for laundering clothes. Water and energy costs are low. Technology has provided an abundance of water and energy, but there is a cost we must face: Our supply of water and energy is limited; our environment is endangered.

The laundry process is hardly what it was in the day of Shannon's great-grandmother, Martha Ann, yet the goals of these principles need to be considered.

1. Q. Is the White-Bixby water hard or soft?

A. Chances are: hard. Most water in Florida homes comes from private wells or municipal water systems that draw water from deep wells.

Q. Can clothes get clean in hard water? A. Synthetic detergents are designed to work well in either hard or soft water.

2. Q. Are heavily soiled clothes soaked? A. Some washers have a soak cycle that leads into the wash cycle. Chances are the family has very few heavily soiled clothes.

3. Q. How do the White-Bixbys sort clothes for colors?

A. Today's dyes are often colorfast and fade little if any. However, some white and man-made fabrics will absorb trace dyes and discolor. Note: Always check labels for washing instructions.

Q. Are clothes regularly sorted for soil? A. Wash lightly soiled clothes separately from heavily soiled items because soil can be redeposited on "clean" clothes making them look dingy. Note: Wash fabrics that shed separately from items that show lint. 
4. Q. Is hot water necessary for getting white clothes clean?

A. Today's engineered detergents and bleaches get good results in cooler water on soil-resistant fabrics. Note: Heavy, oily soils are more easily removed in hot water.

5. Q. Must heavily soiled areas of clothes be pretreated? (Martha Ann scrubbed soiled areas vigorously to get them clean.)

A. Today we pretreat with spot and stain removers or extra detergent rubbed into heavily soiled areas like shirt collars. Given enough time, many spots and soiled areas come clean during the normal washing cycle. The drawback? Clean and soiled areas are given equal friction, increasing fabric wear and causing pilling on some synthetic fabrics.

6. Q. Must clothes be boiled to thoroughly clean and disinfect them?

A. No. Today bleaches clean and disinfect clothes.
7. Q. Would bluing improve the appearance of the White-Bixby family laundry?

A. Probably not. Modern detergents have optical brighteners -- these add ultraviolet light reflection to the light reflected from white clothes -- making whites look extra white.

8. Q. Is starch needed to give fabrics body and a smooth appearance?

A. Most fabrics today have body and are frequently treated to make them wrinklefree or may have pleats or wrinkles set in. Ready-made starch or spray-on finishes are available to give body to cotton or linen if needed.

9. Q. Why don't the White-Bixbys hang clothes out to dry?

A. Clothes dryers do this job and eliminate worry about rain or about sunfading colors. Dryers also take the heavy lifting out of laundering. Dryers need help, too. Clothes feel softer and synthetic fabrics lose static cling if fabric softener is used occasionally. 
Some families line-dry their laundry even today, to save energy, reduce fuel costs and get the fresh smell line-dried laundry can have.

10. Q. How does home laundering impact the environment? How much water is used for the family wash?

A. Water, energy and chemicals are used. 20,000 gallons a year may be used by one family.

Q. What is done with the dirty wash and rinse water when the washing is done?

A. It's down the drain. This waste water must go through a treatment process before reuse.

Q. Are all laundry agents

biodegradable?

A. Synthetic detergents are; other laundry aids may not be. Read labels for instructions on disposing of containers or leftover contents.

\section{Laundry Costs Now}

Each of the elements in the Cleanliness Formula carry a cost, a cost in water, a cost in energy as well.

\section{WATER plus HEAT ENERGY plus CHEMICAL ENERGY plus PHYSICAL ENERGY equals CLEANLINESS.}

How much water? How much does it cost? The White-Bixbys use tap water, not rainwater, for washing clothes. If they wash seven full loads a week, at 50 gallons a load, they use over 18,000 gallons of water in a year. The Cost? The cost of water itself isn't so great - under \$20. The White-Bixbys also pay sewage bills based on the amount of water they use each month. Add $\$ 35$ more to their laundry bill. Even though their utility bill so far isn't astronomical, they do use lot of water for laundering. Assuming their water use for laundry is about average, the five million Florida households can be expected to use some 100 billion gallons per year - just for laundering clothing, bedding and towels.

How much heat energy? What costs? Gas or electricity heated the laundry water. The Cost? The White-Bixbys may use 2,000 kilowatt hours a year to heat water if they have an electric water heater. The dollar cost of that electricity can be about $\$ 150$ per year. With a gas water heater, their annual fuel bill will be much lower about \$20. Thus, the total "bill" for all Florida for heating water for household laundry is somewhere between $\$ 100$ and $\$ 800$ million each year. And, both gas and electrical energy are nonrenewable energy resources.

What chemical energy was used in the cleaning process? What cost? Synthetic detergents, made from petroleum by-products (another non-renewable energy resource), are designed to be biodegradable. Bleach, stain remover, fabric softeners also are used to enhance the appearance and cleanliness of laundry. The costs? Typically, a family like the White-Bixbys can be expected to spend $\$ 100$ or more per year for these laundry supplies. For the five million Florida households in 1994 laundry supplies could amount to $\$ 500$ million per year.

What additional energy was used to clean the clothes? Automatic washers scrub clothes with an agitator. Clothes are moved back and forth and up and down in water in a revolving tub. As the fabrics rub against each other, they scrub dirt or loosen it and the movement of water back and forth separates the dirt from the fabric. Automatic dryers have fans that blow heated air through semi-wet clothes in a rotating drum. The cost? The White-Bixbys wash and dry seven loads of washing a week. The bill for operating their electric washer and dryer can add another $\$ 80$ to $\$ 100$ per year. If all Florida 
households used a washer and dryer for all their laundry, Florida's "bill" for washer and dryer operations might be $\$ 500$ million per year.

Let's add it all up. How much do the WhiteBixbys pay to launder their clothes?

$\$ 20$ for the water

35 for waste water treatment

150 to heat water in their electric water heater

( $\$ 20$ to heat water in a gas water heater) 100 for detergent and laundry additives 100 to operate their washer and dryer $\$ 405$ (\$275 with a gas water heater)

This is truly a bargain in dollars. But we must also consider the cost to the environment.

\section{Environmental Impacts}

Historically, we Americans have given little thought to water and energy as limited resources on a large scale. As we have seen, conservation of water and energy was highly situational varying with the weather and the physical energy levels of the homemaker.

Events of the past 20 to 30 years have brought about a slow recognition of both limited resources (water and energy) and environmental (non-renewable resources) impact. As we discovered, this is especially true of water which is often a non-renewable resource, coming as it does from the thin layer of fresh water riding the surface of the salt water in the Floridan Aquifer.

Environmental impacts of home laundering are not easily calculated. Beyond the obvious the water and energy used by the washer and dryer - it is important to remember there is water and non-renewable energy use required to produce the energy (electric or gas) consumed, the laundry agents (detergent, bleach, fabric softener, pretreating agents), and the laundry equipment (washer, dryer, iron).

Note to Leader. At this point you may want to pass out Fact Sheet FCS 3234 The Conservation Balancing Act: Part III. In the Laundry. Discuss the Table in the fact sheet with comments as follows:

No two washers are alike. No two families wash exactly the same number of loads or use the same load size all the time. This Table serves as an example of ways to conserve water and energy and to save money.

Note that the example shows water and energy costs for doing seven loads a week. That amounts to 365 loads a year using 18,200 gallons per year for a full load (50 gallons) and 10,920 gallons for a partial load ( 30 gallons).

\section{Costs for both water use and waste water} are shown. If you have a private well or are not billed for waste water, ignore those costs when considering how to conserve and save money. Note the big difference in the cost of heating water with gas and electricity.

Next, note how much less energy costs when a warm wash/cold rinse is used instead of a hot water wash/warm water rinse.

Note that a cold wash/cold rinse cycle has NO COST for energy.

Finally, discuss ways participants can reduce the water and energy use in home laundering without sacrificing results - Their Conservation Balancing Act. 
Table 5. Avoiding Laundry Water and Energy Waste ${ }^{1}$

\begin{tabular}{|c|c|c|c|c|c|}
\hline \multicolumn{2}{|c|}{ For One Person } & \multicolumn{2}{|c|}{ Family of 4} & \multicolumn{2}{|c|}{ Cost Per Year - \$ } \\
\hline $\begin{array}{l}\text { Times } \\
\text { Per Week }\end{array}$ & $\begin{array}{l}\text { Gallons } \\
\text { Per Year }\end{array}$ & Water & $\begin{array}{l}\text { Waste } \\
\text { Water }\end{array}$ & $\begin{array}{l}\text { Energy w/ } \\
\text { Elec. Water } \\
\text { Heater }\end{array}$ & $\begin{array}{l}\text { Energy w/ } \\
\text { Gas Water } \\
\text { Heater }\end{array}$ \\
\hline
\end{tabular}

\section{Hot/Warm Wash/Rinse}

Full Load (50 gal)
Partial Load (30 gal)

Warm/Cold Wash/Rinse

Full Load (50 gal)

Partial Load (30 gal)

\section{Cold/Cold Wash/Rinse}

Full Load (50 gal)

Partial Load (30 gal)
7

7

$\$ 18.20$

$\$ 34.58$

10.92

20.75

$\$ 151.60$

$\$ 20.04$

10,920

18,200

18.20

34.58

50.53

6.68

7

10,920

10.92

20.75

30.32

4.01

${ }^{1}$ For assumptions used in the preparation of this table, see the APPENDIX.

The most effective way to save water and water heating costs iso stop leaks and not let water run when not being used. However, just changing from a hot water wash with a warm water rinse to warm water wash and cold rinse or to a cold water wash, cold water rinse can provide energy savings shown here:

\section{Savings Potential}

Hot/Warm minus Warm/Warm

0 gals.

$\$ 0$

$\$ 0$

$\$ 101.07$

$\$ 13.36$

Hot/Warm minus Cold/Cold

0

0

0

0.00

0.00

Note to Leader. After discussing the table go on to talk about how people can conserve and the energy required to heat water for laundering clothes. See Fact Sheet FCS 3234, The Conservation Balancing Act: Part II. In the Laundry. Discuss the list that follows the table for specific ways to conserve water and the energy to heat water when laundering clothes. Ask which of the ideas they now use. Which will they try? 


\section{The Conservation Balancing Act: Part IV. In the Kitchen}

Note to Leader. Water consumption in the kitchen is relatively small compared to the bathroom or laundry. All the same, families who choose to conserve can find ways to save both water and energy without sacrificing the benefits of water use in the kitchen. Discuss first the way water and energy have been used in the kitchen early in the 20th century and how this compares with current practices.

The kitchen is a place for food preparation. The role of sanitation is important here. Raw foods, especially meats, contain microorganisms that can produce toxic substances. Food poisoning is possible when foods become contaminated. There are times when chemicals used in the production of produce should be washed off.

\section{Cleanliness is essential in the kitchen.} Special care is required in refrigerating food, for cleaning and disposing of food wastes. Food is cooked to make it more palatable and, in some cases, safe for consumption.

\section{Water and energy are essential in the kitchen.}

How were water and energy used in the kitchen in the GOOD OLD DAYS? Let's follow Martha Ann Brownly into her kitchen.

\section{Then}

A lot of time was spent in food preparation in the past. It took long hours to prepare foods. There were no "convenience" foods: no frozen foods, no store-bought canned foods, no readybaked breads, cakes or cookies. They were all prepared from "scratch." Most vegetables and fruits consumed were grown at home, had to be nurtured, kept pest-free, harvested and had to be washed before using.

Since water had to be raised from a well or from a pump outside the kitchen and carried into a house, it was precious and was used very wisely. Consider some of the things Martha Ann did each day in her kitchen.

Heating Water Then. Her "modern" kitchen stove had a water reservoir that was filled each morning with soft, rainwater from a cistern. The water in the reservoir stored hot water for washing dishes and to take the chill off the water used for washing hands and faces in the morning and at night. A teakettle was filled as soon as the fire in the stove was going. A big coffeepot was put on (with coffee grounds and an eggshell in it to keep the grounds in the bottom of the pot when the coffee was ready to pour).

Preparing Food Then. In the summer a lot more water was needed because fruit and vegetables were brought from the garden and orchard. Leaves and stems were left in the garden. Peelings were put into a bucket for feeding the pigs. Martha Ann usually washed produce in a large bucket outside, before she brought it in for cooking and canning. It saved her from having to bring clean water in and take dirty water out. Since drawing water was hard, physical labor, she learned to use just the right amount to clean her vegetables and fruit.

Kitchen Cleanup Then. Breakfasts were always heavy because all of the family were engaged in hard work. Other meals also included the accumulation of greasy pots and pans with stuck-on food. The result? Greasy pots and dirty pans to wash with the dishes. Homemade soap made the dishwater sudsy for the first dishes washed, but when it was time to wash the pots and pans the suds were nearly gone. Everything was rinsed with scalding water from the teakettle. It took about two gallons a meal to wash the dishes. Three times a day meant six gallons a 
day. More than 2000 gallons of water was needed to wash all of the family dishes and cookware in a year.

Scrubbing Floors Then. The kitchen floor got hard wear. Scrubbing the kitchen floor was a once a week chore. The floor was always pretty dirty before the week was out.

Consider how Martha Ann's greatgranddaughter, Shannon White-Bixby, uses water in her kitchen.

\section{Now}

Heating Water Today. Shannon has hot water at the kitchen sink, but she can also heat water by turning a knob on her kitchen stove or pushing a button on her microwave. But it is often easier to get hot water at the sink. When water had to be carried in from a well, it was used sparingly. Since water costs are low, and both hot and cold are right where we want them: at the kitchen sink, it is easy for Shannon and her family to waste water and use it carelessly.

Washing Dishes Today. The White-Bixbys may prerinse dishes under a stream of water before putting them into the dishwasher.

Preparing Food Today. They wash salad greens, other fresh vegetables and fruits under a stream of water. Frequently they use canned or frozen foods that don't need washing.

Shannon and her family use water in ways her great-grandmother never did, sometimes thawing frozen food under a stream of water before cooking or serving. Often a little warm or hot water to speed the process.

The White-Bixbys also have a garbage disposer, so peelings and food scraps go down the drain with a lot of water. And there is another water use her great-grandmother never had: Rinsing glass jars. bottles, cans and plastic jugs for recycling.

Scrubbing Floors Today. This isn't a difficult job for Shannon. The home has smooth vinyl floor covering that cleans easily with a sponge mop. A liquid vinyl "wax" keeps dirt on the surface and applies easily.

No two kitchens are the same. Your home equipment and methods may not be exactly the same as the examples, but use them as reliable guides for conserving both water and energy.

Note to Leader. At this point you may refer to the tables in the participants' Fact Sheet FCS 3235. The Conservation Balancing Act: Part IV. In the Kitchen. Discuss the table and Fact Sheet with comments as follows:

To get the Table in perspective, note the amount of water for each use, the number of times for each use per week. Annual costs for a family of four can be cut in half for two, or multiplied by 1.5 for six. (Add one person plus four to reach five.)

Notice that the water, water treatment and water heating costs are much lower in the kitchen than they were for use in the bathroom or laundry.

Prerinsing dishes is estimated at twice a day. Using a dishwasher a family may rinse dishes for breakfast or lunch, put them in the dishwasher and wash the day's dishes altogether after dinner. Using the rinse and hold cycle twice a day would use less water ( 2 times 910 gallons for 1820 gallons per year v. 3640 gallons with hand washing).

Dishwashers use hot water and that means heating energy use as well; you have little choice. But, if you rinse dishes with cold water you are not wasting heating energy. 
Hand-washing dishes under a stream of water is costly. Look what it might take for just heating the water.
Here you may discuss the Ways to Save section of the fact sheet.

Table 6. Avoiding Kitchen Water and Energy Waste ${ }^{1}$

\begin{tabular}{|c|c|c|c|c|c|}
\hline \multicolumn{2}{|c|}{ For One Person } & \multicolumn{2}{|c|}{ Family of 4} & \multicolumn{2}{|c|}{ Cost Per Year - \$ } \\
\hline $\begin{array}{l}\text { Times } \\
\text { Per Week }\end{array}$ & $\begin{array}{l}\text { Gallons } \\
\text { Per Year }\end{array}$ & Water & $\begin{array}{l}\text { Waste } \\
\text { Water }\end{array}$ & $\begin{array}{l}\text { Energy w/ } \\
\text { Elec. Water } \\
\text { Heater }\end{array}$ & $\begin{array}{l}\text { Energy w/ } \\
\text { Gas Water } \\
\text { Heater }\end{array}$ \\
\hline
\end{tabular}

Prerinsing Dishes - Cold Water

$\begin{array}{lrrrr}5 \text { gal } & 14 & 3,640 & \$ 3.64 & \$ 6.55 \\ 3 \text { gal } & 14 & 2,184 & 2.18 & 4.15\end{array}$

Dishwasher

Regular Load (12 gal)

7

4,368

4.37

8.30

$\$ 48.51$

$\$ 6.41$

Short Cycle (8 gal)

2,912

2.91

5.53

32.34

4.28

Rinse and Hold (2.5 gal)

7

0.91

1.73

10.11

1.34

Hand Dishwashing

Under Running Water (16 gal)

20

16,640

16.64

31.62

92.40

12.22

With Pans of Water for

20

6,240

6.24

11.86

34.65

4.58

\section{Disposer}

$\begin{array}{lllll}6 \text { gal } & 10 & 3,120 & 3.12 & 5.93 \\ 5 \text { gal } & 10 & 2,600 & 2.60 & 4.94\end{array}$

Washing Vegetables

$\begin{array}{rrrrr}5 \text { gal } & 7 & 1,820 & 7.28 & 13.83 \\ 2 \text { gal } & 7 & 728 & 2.91 & 5.53\end{array}$

Cooking

$\begin{array}{lrrrr}.5 \text { gal } & 7 & 182 & 0.73 & 1.38 \\ .2 \text { gal } & 7 & 73 & 0.29 & 0.55\end{array}$

${ }^{1}$ For assumptions used in the preparation of this table, see the APPENDIX. 
One of the most effective water saving activities in the kitchen is stopping leaks and not running water when not being used. However, just changing from the most wasteful ways in the chart above (prerinsing dishes, dishwasher washing, disposer use, washing vegetables and cooking) to the most conserving can provide water, waste water and energy savings shown here:

Table 7. Conserving Kitchen Water and Energy

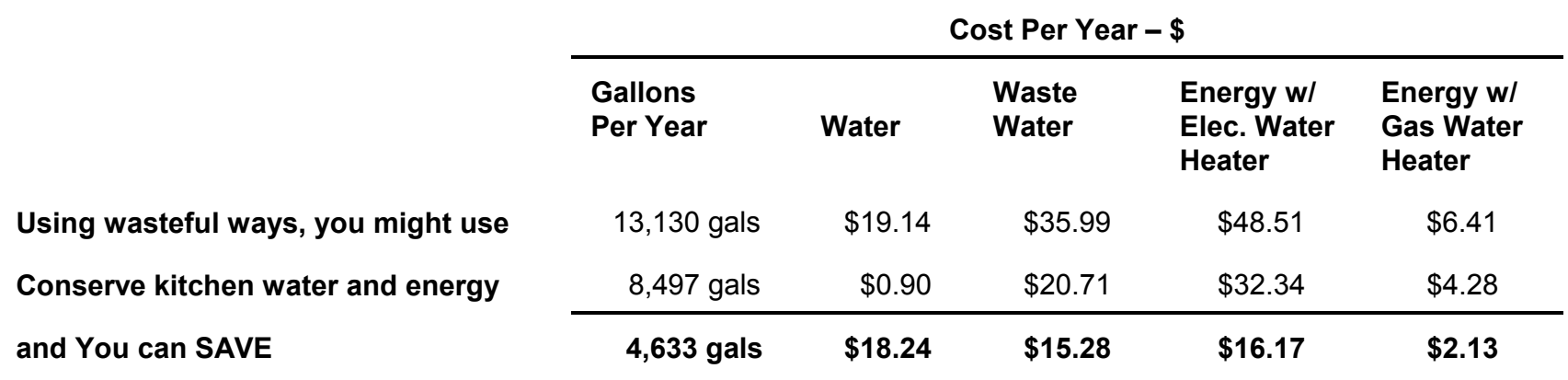

Note to Leader. After discussing the table go on to talk about how people can conserve and the energy required to heat water in their kitchens. See Fact Sheet FCS 3235, The Conservation Balancing Act: Part IV. In the Kitchen. Discuss the list that follows the table for specific ways to conserve water and the energy to heat water in their kitchens. Ask which of the ideas they now use. Which will they try? 


\section{Appendix}

\section{Assumptions used in developing the Tables in the fact sheets.}

In developing the Water/Energy

Conservation table assumptions were made. Individual families will vary in their water and energy use. However, the tables provide a fair comparison of water and energy use and alternatives that encourage conservation. Here are the assumptions:

Family size: Four.

Use: Gallons of water per use and times of use per day is in agreement with other water conservation publications.

Bathroom: Each member of the family uses the same amount of water and type of shower, bath, washing hair, etc., except for shaving (1 person).

Laundry: Washer water use based on industry estimates. These figures vary with manufacturer and model.

Kitchen: Dishwasher and disposer water use based on industry estimates. These figures vary with manufacturer and model. Keep in mind, automatic dishwashers use hot water only. For hand dishwashing, assumption was that warm water (half hot and half cold) would be used.

\section{Cost of utilities:}

Water $-\$ 0.99$ per 1000 gallons.

Waste Water $-\$ 1.90$ per 1000 gallons based on water use.

Electricity - \$0.075 per KWH.

Natural Gas $-\$ 0.26$ per Therm.

Water Heating based on raising water temperature $60^{\circ} \mathrm{F}$ ( 70 to $130^{\circ} \mathrm{F}$ for hot water).

For Hot/Warm wash Wash all hot, rinse $50 \%$ hot.

For Warm/Cold wash Wash 50\% hot, rinse cold.

For Cold/Cold wash - No hot water.

All uses of warm water - 50\% hot water.

Water Heater Efficiency - Fairly efficient. Electric - 95\%

Natural Gal - 85\% 